\title{
RELAKSASI PERNAFASAN DENGAN ZIKIR UNTUK MENGURANGI KECEMASAN MAHASISWA
}

\author{
Aulia Syifa ${ }^{1}$ \\ Mufidatul Khairiyah \\ Setia Asyanti \\ Fakultas Psikologi Universitas Muhammadiyah Surakarta, \\ Surakarta
}

\begin{abstract}
Breathing relaxation with zikir is one way to give physical and psychological calm to humans.The purpose of this study was to know the effect of breathing relaxation with zikir on decreasing student anxiety. The hypothesis of this study is that there is a significant decrease in anxiety before and after intervention. This research is an experimental study with one group pretest posttest design. Data collection uses the Anxiety Scale. Data analysis used the Wilcoxon technique with the help of the SPSS 15.0 statistical program. The results of the study show that the value of $Z$ count $=-2,345$ with $p=0,019(p<0,05)$. So it can be concluded that there is a significant decrease in anxiety before and after intervention. Based on these results, then breathing relaxation with zikir is able to be one of the solutions to reduce student anxiety.
\end{abstract}

Key words: breathing relaxation, zikir, anxiety, students

\begin{abstract}
ABSTRAK. Relaksasi pernafasan dengan zikir adalah salah satu cara untuk memberikan ketenangan fisik maupun psikis pada manusia. Tujuan penelitian ini untuk mengetahui pengaruh relaksasi pernafasan dengan zikir terhadap penurunan kecemasan mahasiswa. Hipotesis dari penelitian ini: ada penurunan kecemasan yang signifikan sebelum dan sesudah intervensi. Desain penelitian eksperimen ini adalah one group pretest posttest design. Pengumpulan data menggunakan skala kecemasan. Analisis data menggunakan teknik wilcoxon dengan bantuan program statistik SPSS 15.0. Hasil penelitian menunjukkan bahwa nilai $Z$ hitung $=-2,345$ dengan $p=0,019(p<0,05)$. Dapat disimpulkan bahwa ada penurunan kecemasan yang signifikan sebelum dan sesudah intervensi. Artinya, relaksasi pernafasan dengan zikir mampu menjadi salah satu solusi untuk mengurangi kecemasan mahasiswa.
\end{abstract}

Kata kunci: relaksasi pernafasan, zikir, kecemasan, mahasiswa

\footnotetext{
${ }^{1}$ Korespondensi mengenai artikel dapat melalui : asyifa090196@gmail.com
} 
Kecemasan merupakan salah satu gangguan mental terbesar di dunia. Dari 264 juta kasus kecemasan, 23\% nya terjadi di wilayah Asia Tenggara, sedangkan di wilayah Indonesia prevalensi kecemasannya sebesar 3,3\% (WHO, 2017). Penelitian yang dilakukan Widiani, Yudha K., dan Kusuma (2017) menunjukkan bahwa mahasiswa semester IV sampai VI, program studi ilmu keperawatan Universitas Tribhuwana Tunggadewi Malang, yang akan melaksanakan ujian akhir semester, mempunyai tingkat kecemasan tinggi yaitu $74,6 \%$ dari total 59 responden. Kondisi kecemasan ini merupakan dampak dari beban yang ada pada mahasiswa tersebut. Kemudian, dijelaskan bahwa 30\% responden berumur 21 tahun mengalami tingkat kecemasan yang lebih tinggi. Kecemasan mudah terjadi pada mahasiswa tingkat akhir, karena mereka mempunyai beberapa tuntutan yang harus dipenuhi seperti lulus tepat waktu, tugas-tugas perkuliahan yang harus diselesaikan, dan juga ujian yang harus dihadapi.

Penelitian Widodo, Laelasari, Sari, Dewi, dan Putrianti (2017) memaparkan bahwa ada hubungan yang negatif antara tingkat kecemasan terhadap motivasi belajar mahasiswa pada mata kuliah matematika tahun akademik 2013 - 2014 dengan sumbangan efektifnya sebesar 30\%. Mahasiswa yang memiliki tingkat kecemasan rendah memiliki kecenderungan motivasi yang tinggi, tetapi jika mahasiswa tersebut memiliki tingkat kecemasan yang tinggi memiliki kecenderungan motivasi yang rendah.

Berbicara tentang kecemasan, mahasiswa pun tidak luput dari masalahnya. Salah satu contoh yang terjadi pada mahasiswa kelas A mata kuliah Terapi Perilaku Kognitif atau Cognitive Behavior Therapy (CBT) di Fakultas Psikologi Universitas Muhammadiyah Surakarta (UMS). Pada mata kuliah tersebut dosen memberikan tugas secara rutin pada setiap pertemuan. Mahasiswa diminta menganalisis masalah yang sedang dihadapi masing-masing mahasiswa. Menurut hasil wawancara dengan beberapa mahasiswa bahwa tugas yang diberikan mata kuliah tersebut tidak jarang membuat cemas para mahasiswa, karena mahasiswa merasa sulit mengerjakannya. Ada berbagai alasan mengapa mahasiswa sulit mengerjakan tugas mata kuliah tersebut, yakni mahasiswa sulit menganalisa masalahnya sendiri, ada beberapa mahasiswa yang tidak mau mengungkap masalahnya karena baginya itu terlalu berat, dan mahasiswa takut jika nantinya masalahnya diketahui teman-temannya. Ditambah lagi terdapat satu hal yang dialami hampir seluruh mahasiswa, yaitu masih banyak pula beban tugas dari mata kuliah lain. Berdasarkan hasil wawancara singkat dengan beberapa mahasiswa, diketahui bahwa upaya mahasiswa selama ini dalam mengatasi kecemasan yang dialami adalah dengan menghindar dari tugas, mendengarkan musik, nonton film, dan hal-hal yang menghibur lainnya.

Dari beberapa masalah tersebut menunjukkan bahwa kecemasan mahasiswa dapat berpengaruh negatif terhadap diri mahasiswa. Masalah negatif tersebut bukanlah sesuatu yang diharapkan, karena dapat mempengaruhi performa mahasiswa dalam menempuh perkuliahan. Untuk menghindari pengaruh negatif dari kecemasan, maka diperlukan adanya intervensi yang mampu menurunkan kecemasan mahasiswa. Berdasarkan studi pustaka, salah satu intervensi yang dapat dilakukan adalah dengan melakukan relaksasi pernafasan dengan zikir. Namun, perlu diketahui terlebih dahulu bagaimana pengaruh relaksasi pernafasan dengan zikir terhadap penurunan kecemasan mahasiswa. Seharusnya, jika melakukan relaksasi pernafasan dengan zikir, akan didapatkan beberapa manfaat. Selain mendapatkan 
manfaat dari relaksasi, juga mendapatkan manfaat dari penggunaan keyakinan. Manfaat dari relaksasi adalah dapat menurunkan kecemasan sehingga rasa sakit dapat berkurang (Sulistyarini, 2013). Sedangkan manfaat dari penggunaan keyakinan yaitu menambah keimanan (Purwanto, 2006).

Relaksasi adalah salah satu teknik di dalam teori terapi perilaku kognitif (Purwanto, 2006). Menurut McNeil \& Lawrence, relaksasi merupakan metode atau teknik yang digunakan untuk membantu manusia belajar mengurangi atau mengontrol reaktivitas fisiologis yang menimbulkan masalah bagi dirinya (Maimunah \& Retnowati, 2011). Tujuan relaksasi adalah untuk mengurangi tingkat gejolak fisiologis individu dan membawa individu ke keadaan yang lebih tenang baik secara fisik maupun psikologis (Rout \& Rout dalam Maimunah \& Retnowati, 2011).

Pernafasan merupakan relaksasi dengan cara mengatur langkah dan kedalaman pernafasan (Schaffer dalam Maimunah \& Retnowati, 2011). Davis, Eshelman, \& McKay menyatakan bahwa pernafasan yang tepat merupakan pereda stres (Maimunah \& Retnowati, 2011). Relaksasi dapat sebagai active coping skill jika digunakan untuk mengajar individu kapan dan bagaimana menerapkan relaksasi dibawah kondisi yang diinginkan, misalnya digunakan untuk mengurangi gangguan insomnia, mengurangi kecemasan atau untuk membuat tubuh istirahat sejenak (Purwanto, 2006). Apabila individu melakukan relaksasi ketika ia mengalami ketegangan atau kecemasan, maka reaksireaksi fisiologis yang dirasakan individu akan berkurang, sehingga la akan merasa rileks. Apabila kondisi fisiknya sudah rileks, maka kondisi psikisnya juga tenang (Lichstein dalam Purwanto, 2006).

Berkaitan dengan zikir, dapat diketahui bahwa zikir (ingat Allah) merupakan kegiatan yang banyak dilakukan umat Islam karena zikir merupakan dasar dari seluruh ritual ibadah, bahkan dikatakan bahwa zikir merupakan ruhnya semua ibadah karena dengan ingat Allah itulah letak transendensi (Purwanto, 2006). Zikir secara etimologi berasal dari kata az-zikr yang artinya adalah ingat. Zikir berarti mengingat Allah (Saleh dalam Maimunah \& Retnowati, 2011). Zikir ialah mengingat nikmat-nikmat Tuhan. Lebih jauh, berzikir meliputi pengertian menyebut lafal-lafal zikir dan mengingat Allah dalam setiap waktu, takut dan berharap hanya kepadaNya, merasa yakin bahwa diri manusia selalu berada dibawah kehendak Allah dalam segala hal dan urusannya (AshShiddieqy dalam Maimunah \& Retnowati, 2011). Zikir membantu individu membentuk persepsi yang lain selain ketakutan yaitu keyakinan bahwa stresor apapun akan dapat dihadapi dengan baik dengan bantuan Allah (Maimunah \& Retnowati, 2011). zikir kepada Allah itu bukan sekedar ungkapan sastra, nyanyian, hitungan-hitungan lafadz, melainkan suatu hakikat yang diyakini didalam jiwa dan merasakan kehadiran Allah di segenap keadaan, serta berpegang teguh dan menyandarkan kepadaNya hidup dan matinya hanya untuk Allah semata (Sangkan dalam Purwanto, 2006).

Lebih lanjut, relaksasi zikir merupakan respon relaksasi yang dikembangkan Benson (dalam Purwanto, 2006), dimana relaksasi ini merupakan gabungan antara relaksasi dengan keyakinan agama yang dianut. Respon relaksasi yang melibatkan keyakinan yang dianut akan mempercepat terjadinya keadaan relaks, dengan kata lain kombinasi respon relaksasi dengan melibatkan keyakinan akan melipat gandakan manfaat yang didapat dari respon relaksasi (Benson dalam Purwanto, 2006). Semakin kuat keyakinan seseorang berpadu dengan respon relaksasi maka semakin besar pula efek relaksasi yang didapat. Fokus dari relaksasi ini tidak pada 
pengendoran otot namun pada frase tertentu yang diucapkan berulang kali dengan ritme yang teratur disertai sikap pasrah kepada objek transendensi yaitu Tuhan. Frase yang digunakan dapat berupa nama-nama Tuhan, atau kata yang memiliki makna menenangkan.

Hipotesis dari penelitian ini, yaitu ada penurunan kecemasan yang signifikan antara sebelum dan sesudah intervensi.

\section{METODE PENELITIAN}

\section{Subjek Penelitian}

Penelitian ini dilaksanakan di Fakultas Psikologi Universitas Muhammadiyah Surakarta pada semester ganjil tahun ajaran 2016/2017 tepatnya hari Jumat tanggal 7 Oktober 2016. Populasi dari penelitian ini adalah mahasiswa kelas A mata kuliah Cognitive Behavior Therapy (CBT) Fakultas Psikologi UMS dengan jumlah 25 mahasiswa. Teknik sampling dalam penelitian ini adalah sampel jenuh. Sampel diambil satu kelas penuh, yaitu kelas A sebagai eksperimen.

\section{Desain Penelitian}

Metode penelitian yang digunakan adalah eksperimen dengan desain one group pretest posttest design, dengan menggunakan satu kelompok sebagai sampel, dimana sekelompok subjek diberikan perlakuan dalam jangka waktu tertentu. Pengukuran dilakukan sebelum dan sesudah perlakuan diberikan. Perbedaan antara hasil pengukuran awal dengan hasil pengukuran akhir merupakan pengaruh perlakuan yang diberikan.

\section{Metode Pengumpulan Data}

Pengumpulan data dalam penelitian ini menggunakan Skala Kecemasan yang merupakan modifikasi dari penelitian Machmudati (2013) dengan jumlah 25 aitem yang memiliki nilai alpha sebesar
0,901 dengan rentang skor indeks daya beda dari 0,3 sampai 0,8 .

\section{Prosedur Intervensi}

Langkah-langkah eksperimen yang dilakukan peneliti, berdasarkan modifikasi penelitian dari Purwanto (2006) yakni sebagai berikut:

Pertama: Terlebih dahulu mahasiswa dibagikan kuesioner prates.

Kedua: Setelah itu, mahasiswa diberikan penjelasan tentang materi relaksasi pernafasan dengan zikir.

Ketiga: Setelah pemberian materi mahasiswa diminta untuk persiapan terapi relaksasi pernafasan dengan zikir. Persiapan dilakukan dengan meletakkan tas yang berada di kursi untuk diletakkan dibawah meja.

Keempat: Lalu mahasiswa diminta memposisikan duduk senyaman mungkin.

Kelima: Setelah itu, mahasiswa dipandu oleh instruktur untuk mulai memejamkan mata secara perlahan lahan.

Keenam: Mahasiswa kemudian diminta untuk melemaskan otot mulai dari kaki, kemudian betis, paha, dan perut seterusnya hingga kepala. Caranya dengan merasakan otot yang akan dirilekskan kemudian otot tersebut diperintahkan untuk rileks misalnya akan melemaskan otot kaki; dengan memerintahkan pada kaki "lemas.. lemas.." sambil merasakan dan membiarkan otot-otot kaki untuk lemas.

Ketujuh: Oleh instruktur mahasiswa diminta menarik nafas sambil mengatakan "yaa.." dalam hati. Kemudian instruktur meminta mahasiswa untuk menahan nafas selama lima detik sambil instruktur melakukan hitungan secara perlahan dari satu sampai lima.

Kedelapan: Setelah lima detik, mahasiswa diminta untuk mengehembuskan nafas 
secara perlahan-lahan sambil mengucapkan kata "Allah.." dalam hati.

Kesembilan: Instruktur meminta mahasiswa untuk mengulangi langkah tersebut sambil dipandu olehnya kurang lebih selama 30 menit.

Kesepuluh: Setelah itu mahasiswa diminta membuka mata kembali dan duduk seperti semula.

Kesebelas: Terakhir mahasiswa dibagikan kuesioner pascates

\section{Metode Analisis Data}

Analisis data menggunakan statistic non parametric dengan teknik analisis wilcoxon untuk mengetahui penurunan kecemasan mahasiswa kelas A mata kuliah Cognitive Behavior Therapy (CBT) Fakultas Psikologi UMS. Taraf signifikansi yang digunakan penulis adalah 5\%. Perhitungan seluruh data penelitian ini menggunakan program komputer SPSS 15.0 for windows. Hasil uji normalitas menunjukkan bahwa data pre-test normal dan post-test tidak normal (lihat Tabel 1).

Tabel 1. Hasil Uji Normalitas

\begin{tabular}{lcccccc}
\hline & \multicolumn{3}{c}{ Kolmogorov-Smimov $^{a}$} & \multicolumn{3}{c}{ Shapiro-Wilk } \\
\cline { 2 - 7 } & Statistic & $d f$ & Sig. & Statistic & $d f$ & Sig. \\
\hline Pre test &, 093 & 25 &, $200^{*}$ &, 983 & 25 &, 935 \\
Post test &, 215 & 25 &, 004 &, 865 & 25 &, 003 \\
\hline
\end{tabular}

\section{HASIL PENELITIAN}

Penelitian ini bertujuan untuk mengetahui pengaruh relaksasi pernafasan dengan zikir terhadap penurunan kecemasan mahasiswa kelas A mata kuliah Cognitive Behavior Therapy (CBT) Fakultas Psikologi Universitas Muhammadiyah Surakarta. Prosedur penelitian yang dilakukan yaitu dengan memberikan Skala Kecemasan (prates) kepada mahasiswa untuk mengetahui tingkat kecemasan mahasiswa sebelum diberikan perlakuan.
Kemudian setelah pemberian perlakuan yaitu mahasiswa melakukan relaksasi pernafasan dengan zikir, peneliti memberikan Skala Kecemasan lagi (pascates) untuk mengetahui tingkat kecemasan setelah diberikan perlakuan. Hasil prates dan pascates tersebut dijadikan dasar untuk mengetahui perbedaan tingkat kecemasan mahasiswa setelah diberikan perlakuan.

Data tentang tingkat kecemasan mahasiswa, peneliti sajikan sebagai berikut:

Tabel 2. Hasil Deskriptif Statistik

\begin{tabular}{lccccc}
\hline & N & Mean & Std. Deviation & Minimum & Maximum \\
\hline Pre test & 25 & 60,3600 & 10,21388 & 37,00 & 78,00 \\
Post test & 25 & 56,6400 & 8,27587 & 28,00 & 70,00 \\
\hline
\end{tabular}

Berdasarkan hasil prates mahasiswa, diperoleh data nilai tertinggi sebesar 78 dan nilai terendah sebesar 37 dengan rata-rata kelas sebesar 60,36.

Berdasarkan hasil pascates mahasiswa, diperoleh data nilai tertinggi sebesar 70 dan nilai terendah sebesar 28 dengan rata-rata kelas sebesar 56,64.

Adanya selisih nilai rata-rata antara prates dan pascates tersebut menunjukkan bahwa terdapat perbedaan tingkat kecemasan mahasiswa setelah diberikan perlakuan. 
Tabel 3. Hasil Tes Statistik

\begin{tabular}{cc}
\hline & post test-pre test \\
\hline $\mathrm{Z}$ & $-2,345^{\mathrm{a}}$ \\
Asymp. Sig. (2-tailed) &, 019 \\
\hline
\end{tabular}

Berdasarkan hasil uji hipotesis perhitungan nilai prates dan pascates mengenai tingkat kecemasan mahasiswa dihasilkan nilai $\mathrm{Z}$ hitung $=-2,345$ dengan $\mathrm{p}$ $=0,019$ artinya hipotesis yang diajukan peneliti diterima. Sehingga dapat disimpulkan bahwa relaksasi pernafasan dengan zikir berpengaruh terhadap penurunan kecemasan mahasiswa kelas $\mathrm{A}$ mata kuliah Cognitive Behavior Therapy (CBT) Fakultas Psikologi Universitas Muhammadiyah Surakarta.

\section{PEMBAHASAN}

Hipotesis dalam penelitian ini terbukti berpengaruh yaitu relaksasi pernafasan dengan zikir secara signifikan dapat menurunkan tingkat kecemasan mahasiswa kelas A mata kuliah Cognitive Behavior Therapy (CBT) Fakultas Psikologi Univeristas Muhammadiyah Surakarta. Hal ini terlihat dari nilai Z hitung $=-2,345$ yang signifikan pada taraf signifikansi 0,019 $(\mathrm{p}<0,05)$. Hasil penelitian ini mendukung beberapa penelitian sebelumnya yang menyatakan bahwa relaksasi dapat mengatasi kecemasan (Maimunah dan Retnowati, 2011; Murni, dkk., 2014; Kartika dan Subandi, 2015).

Penelitian yang dilakukan Maimunah dan Retnowati (2011) membuktikan bahwa pelatihan relaksasi dengan zikir secara signifikan dapat mengurangi kecemasan subjek dalam menghadapi kehamilan pertama, dibuktikan dengan hasil uji Mann Whitney $U$ yang signifkan pada taraf signifkansi $0,008 \quad(\mathrm{p}<0,01)$. Kemudian, penelitian yang dilakukan Murni dkk
(2014) membuktikan bahwa latihan relaksasi guided imagery and music di kelas prenatal efektif dapat mengurangi kecemasan ibu saat pengalaman persalinan mereka dengan hasil perbedaan yang signifikan dari skor kecemasan sebelum dan sesudah perlakuan, pada kelompok intervensi $(p=0,001)$ dan pada kelompok kontrol $(p=0,016)$.

Penelitian lain, yang dilakukan Kartika dan Subandi (2015), membuktikan bahwa pemberian pelatihan teknik relaksasi dapat menurunkan tingkat kecemasan pada keluarga yang merawat penderita kanker, memberikan efek positif bagi keluarga yang dibuktikan dengan hasil analisis perbedaan Wilcoxon menunjukkan skor kecemasan tampak mengalami penurunan pada setiap pengukurannya yakni nilai $Z=-2,041$ dan $p=0,0205(p<0,05)$.

Penelitian ini juga menguatkan penelitian-penelitian sebelumnya yang telah membuktikan bahwa terapi relaksasi pernafasan yang disertai dengan zikir (berbasis keislaman) terbukti dapat meningkatkan kesehatan mental dengan cara mengurangi kecemasan subjek (Maimunah dan Retnowati, 2011; Purwanto, 2006). Bedanya, penelitian ini mengkhususkan subjek pada mahasiswa. Penelitian ini menambahkan fakta bahwa terapi berbasis keislaman juga dapat membantu menurunkan kecemasan mahasiswa. Relaksasi pernafasan dengan zikir adalah sebuah metode yang digunakan dengan harapan dapat mengurangi kecemasan mahasiswa, yang selama ini merasa cemas dengan berbagai tugas-tugas yang diberikan dosen. 


\section{SIMPULAN DAN SARAN}

Penelitian ini dilakukan untuk mengetahui pengaruh relaksasi pernafasan dengan zikir terhadap penurunan kecemasan mahasiswa kelas A mata kuliah Cognitive Behavior Therapy (CBT) Fakultas Psikologi UMS. Berdasarkan analisis data dan pembahasan hasil penelitian, dapat ditarik kesimpulan bahwa relaksasi pernafasan dengan zikir berpengaruh terhadap penurunan kecemasan mahasiswa kelas A mata kuliah Cognitive Behavior Therapy (CBT) Fakultas Psikologi UMS. Berdasarkan hasil penelitian ini, peneliti memberikan saran sebagai berikut:

Pertama bagi mahasiswa, penelitian ini diharapkan dapat membantu mahasiswa mengatasi kecemasan yang dialami terutama ketika di lingkungan perkuliahan. Kedua bagi dosen, diharapkan hasil penelitian ini bisa dijadikan salah satu langkah mengatasi kecemasan yang dialami mahasiswanya sehingga bisa di aplikasikan sebelum jam belajar mengajar dimulai supaya pembelajaran yang diterima mahasiswa lebih efektif. Ketiga bagi peneliti lain, diharapkan melakukan penelitian dengan ditambahkan pembanding berupa kelompok kontrol, mempersiapkan instrumen pengukuran dengan lebih baik, dan melakukan follow up setelah selesainya intervensi untuk mengetahui apakah pengaruh dari intervensi yang dilakukan masih tetap dirasakan atau tidak.

\section{DAFTAR PUSTAKA}

Kartika Sari, A. D., \& Subandi. (2015). Pelatihan Teknik Relaksasi untuk Menurunkan Kecemasan pada Primary Caregiver Penderita Kanker Payudara. Gadjah Mada Journal of Professional Psychology, 173 - 192.

Machmudati, A. (2013). Efektivitas Pelatihan Berpikir Positif Untuk Menurunkan Kecemasan Mengerjakan Skripsi Pada Mahasiswa Fakultas Umum UIN Sunan Kalijaga Yogyakarta. (Skripsi, tidak diterbitkan). Universitas Islam Negeri Sunan Kalijaga, Yogyakarta, Indonesia

Maimunah, A., \& Retnowati, S. (2011). Pengaruh Pelatihan Relaksasi Dengan Zikir Untuk Mengatasi Kecemasan Ibu Hamil Pertama. Psikoislamika, 1-22.
Murni, N. A., Suhartono, \& Suherni, T. (2014). Pengaruh Latihan Relaksasi Guided Imagery and Music (GIM) pada Kelas Ibu Terhadap Derajat Kecemasan Ibu Hamil Menghadapi Persalinan Pertama. Jurnal Kesehatan Prima, 1197-1206.

Purwanto, S. (2006). Relaksasi Zikir. Suhuf, 39-48.

Sulistyarini, I. (2013). Terapi Relaksasi untuk Menurunkan Tekanan Darah dan Meningkatkan Kualitas Hidup Penderita Hipertensi. Jurnal Psikologi, 28-38.

WHO. (2017). Depression and Other Common Mental Disorders. Geneva, Switzerland: WHO Document Production Services. 
Widiani, Esti, Yudha K., Satria, Kusuma, Farida Halis Dyah. (2017). Hubungan Antara Tingkat Kecemasan dengan Kejadian Insomnia pada Mahasiswa yang Akan Menghadapi Ujian Akhir Semester (UAS) di Universitas Tribhuwana Tunggadewi Malang. Nursing News, 2 (1), 543-554.
Widodo, S. A., Laelasari, Sari, R. M., Dewi,N.I. R., \& Putrianti, F. G. (2017). Analisis Faktor Tingkat Kecemasan, Motivasi dan Prestasi Belajar Mahasiswa. Jurnal Taman Cendekia, 67-77. 